\title{
Pelatihan Kewirausahaan Ekonomi Kreatif Karang Taruna Tanah Putih Kabupaten Rokan Hilir
}

\author{
Meimunah S. Moenada \\ UIN Suska Riau, meimunah.s.moenada@uin-suska.ac.id \\ Hendra Riofita \\ UIN Suska Riau, hendrariofita@yahoo.com
}

\begin{abstract}
The objective of this dedication was to prepare the Youth of Karang Taruna Kecamatan Tanah Putih Kabupaten Rokan Hilir as spearhead of poverty eradication toward ability to increase creative economic effort for themselves, organization and the communities around them, to train them to do creative economic business toward converting used goods to be goods having sale value and to help them to build their own creative economic business. The methods applied were presentation, games, case study, question and answer and all methods were applie by using andragogy approach. The result showed that all trainees were enthusiastic to have their own business. It was proved by the plans to set up business they presented. Besides all trainees could concert used goods to be goods having sale value like wallet, tissue box, pencil box, rice box, egg box and bag.
\end{abstract}

Keywords: Training, Entrepreneurship, Creative Economics

\section{PENDAHULUAN}

\section{Analisis Situasi}

Kecamatan Tanah Putih tersebar ke sepuluh desa. Dengan merupakan salah satu kecamatan di tingkat pertumbuhan penduduk sebesar

Kabupaten Rokan Hilir Provinsi Riau. 4,8\%, Kecamatan Tanah Putih masih

Berdasarkan sensus terakhir dari Badan termasuk kedalam Kecamatan miskin di

Pusat Statistik Provinsi Riau, Kabupaten Rohul dengan tingkat Kecamatan yang luas wilayahnya kemiskinan mencapai angka 7\%. Mata 1.933,23 Km2 ini, memiliki jumlah pencaharian masyarakat yang dominan penduduk sebanyak 57.500 jiwa yang pada usaha pertanian dan perkebunan, 
ternyata tidak begitu mampu mengangkat kehidupan mereka karena sebagian besar dari mereka tersebut bekerja sebagai buruh tani dan kebun pada lahan-lahan yang dibeli atau dimiliki oleh perusahaan dan atau pemodal yang berasal dari luar Kecamatan Tanah putih.

Banyak hal yang sudah dilakukan oleh Pemerintah Pusat maupun Pemerintah Daerah untuk mengentaskan kemiskinan di Kecamatan Tanah Putih ini seperti Program Asistensi Lanjut Usia (AITUT) untuk usia 60 tahun keatas, Program Kelompok Usaha Bersama Fakir Miskin (Kube-FM), dimana setiap kelompok diberi bantuan sebesar Rp 20.000.000,-, untuk mengembangkan usaha pakan ternak ikan dan usaha kelontong.

Selanjutnya juga ada bantuan Program Keluarga Harapan yang diberikan secara tetap kepada ibu keluarga kurang mampu sebesar Rp 240.000,- dan kepada ibu hamil dan nifas sebesar Rp 1.000.000,-.Dibidang pendidikan, Pemerintah Kabupaten Rokan Hilir juga memberikan bantuan bagi keluarga miskin dengan rincian sebesar Rp 500.000,- bagi anak Sekolah
Dasar dan Rp 1.000.000,- bagi anak Sekolah Menengah Pertama.

Melihat dari gencarnya pemerintah dalam mengentaskan kemiskinan bagi masyarakat di Kecamatan Tanah Putih Kabupaten Rokan Hilir ini, para pengabdi, dosen dari Program Studi Pendidikan Ekonomi Fakultas Tarbiyah dan Keguruan Universitas Islam Negeri Sultan Sarif Kasim Riau merasa terpanggil untuk membantu agenda pemerintah tersebut dengan memberikan pelatihan ekonomi kreatif sebagai wujud pengabdian kami dalam pengentasan kemiskinan bagi masyarakat Riau umumnya dan masyarakat Kecamatan Tanah Putih Kabupaten Rokan Hilir khususnya. Adapun niat dan maksud kami ini didasarkan kepada sabda Nabi Shallallahu 'alaihi wa sallam (dari Abu Hurairah Radhiyallahu anhu) "Barangsiapa yang melapangkan satu kesusahan dunia dari seorang Mukmin, maka Allâh melapangkan darinya satu kesusahan di hari Kiamat. Barangsiapa memudahkan (urusan) orang yang kesulitan (dalam masalah hutang), maka Allâh Azza wa Jalla memudahkan 
baginya (dari kesulitan) di dunia dan akhirat. Barangsiapa menutupi (aib) seorang Muslim, maka Allâh akan menutup (aib)nya di dunia dan akhirat. Allâh senantiasa menolong seorang hamba selama hamba tersebut menolong saudaranya. Barangsiapa menempuh jalan untuk menuntut ilmu, maka Allâh akan mudahkan baginya jalan menuju Surga. Tidaklah suatu kaum berkumpul di salah satu rumah Allâh (masjid) untuk membaca Kitabullah dan mempelajarinya di antara mereka, melainkan ketenteraman akan turun atas mereka, rahmat meliputi mereka, Malaikat mengelilingi mereka, dan Allâh menyanjung mereka di tengah para Malaikat yang berada di sisi-Nya. Barangsiapa yang diperlambat oleh amalnya (dalam meraih derajat yang tinggi-red), maka garis keturunannya tidak bisa mempercepatnya."

Namun demikian, karena banyak jumlah penduduk, serta keterbatasan waktu dan dana, pada kesempatan ini, pelatihan ekonomi kreatif tersebut hanya diberikan kepada pengurus dan anggota Karang Taruna Kecamatan Tanah Putih Kabupaten Rohil saja.
Dipilihnya Karang Taruna ini sebagai sasaran pelatihan karena Karang Taruna beranggotakan para pemuda yang akan menjadi generasi penerus. Hal ini sesuai dengan sabda Rasulullah SAW "Didiklah anak-anak kalian, sebab mereka diciptakan untuk suatu masa yang berbeda dari masa yang kalian hadapi (Hadists Syarif).

Disamping alasan diatas, Karang Taruna juga dipandang memiliki fungsi yang sejalan dengan agenda pembangunan pemerintah yang antara lain seperti yang tertuang dalam Permensos No. 77 Tahun 2005 sebagai berikut: (a) Penyelenggara Pendidikan dan Pelatihan bagi masyarakat, (b) Penyelenggara pemberdayaan masyara kat terutama generasi muda dilingkunggannya secara komprehensif , terpadu dan terarah serta berkesinambungan, Penyelenggara kegiatan pengembanga $\mathrm{n}$ jiwa kewirausahaan bagi generasi muda di lingkungannya dan (d) Pemupukan kreatifitas generasi muda untuk dapat mengembangkan tanggung jawab sosi al yang bersifat rekreatif, kreatif, edukatif, ekonomis 
produktif

dan

kegiatan praktis lainnya dengan mendayagunakan segala sumber dan potensi kesejahteraan sosial di lingkungannya secara swadaya.

Dari fungsi-fungsi Karang Taruna tersebut, jelaslah bahwa diharapkan setelah mendapatkan pelatihan ekonomi kreatif tersebut, para pengurus dan anggota Karang Taruna Kecamatan Tanah Putih Kabupaten Rokan Hilir Privinsi Riau bisa menjadi ujung tombak dalam mengentaskan kemiskinan dan memajukan perekonomian masyarakat di sekitarnya.

\section{Perumusan Masalah}

Berdasarkan analisis situasi diatas, dapatlah diidentifikasikan bahwa masyarakat Kecamatan Tanah Putih Kabupaten Rokan Hilir Provinsi Riau masih banyak yang hidup dalam kemiskinan dan peranan pemuda terutama yang bergabung dalam Karang Taruna belumdapat dikatakan signifikan dalam mejalankan fungsi mereka dalam menyukseskan agenda pembangunan pemerintah yang salah satunya mengentaskan kemiskinan. Berdasarkan kenyataan ini, dapatlah dirumuskan masalah sebagai berikut: a. Bagaimana menyadarkan pemuda akan peran penting pemuda Karang Taruna di Kecamatan Tanah Putih Kabupaten Rokan Hilir Provinsi Riau dalam pengentasan kemiskinan?

b. Bagaimana cara meningkatkan pengetahuan dan pemahaman serta keterampilan pemuda Karang Taruna di Kecamatan Tanah Putih Kabupaten Rokan Hilir Provinsi Riau tentang ekonomi kreatif?

c. Bagaimana membuat usaha ekonomi kreatif bagi pemuda Karang Taruna di Kecamatan Tanah Putih Kabupaten Rokan Hilir Provinsi Riau?

\section{Tujuan}

Tujuan yang ingin dicapai dalam pengabdian masyarakat ini adalah:

a. Menjadikan pemuda Karang Taruna Kecamatan Tanah Putih Kabupaten Rokan Hilir sebagai ujung tombak pengentas kemiskinan melalui kemampuan meningkatkan usaha ekonomi kreatif bagi dirinya, organisasinya dan masyarakat disekitarnya;

b. Melatih pemuda Karang Taruna Kecamatan Tanah Putih Kabupaten Rokan Hilir untuk dapat melakukan 
usaha ekonomi kreatif dengan mengubah barang bekas menjadi barang yang punya nilai jual;

c. Membantu pemuda Karang Taruna Kecamatan Tanah Putih Kabupaten Rokan Hilir untuk dapat membuat usaha ekonomi kreatif.

\section{Manfaat}

a. Bagi Pemuda Karang Taruna Serta Masyarakat Kecamatan Tanah Putih Kabupaten Rokan Hilir; dapat membuka peluang berusaha secara kreatif dengan mengubah barang bekas menjadi barang yang punya nilai jual sehingga dapat meningkatkan perekonomian.

b. Bagi UIN Suska Riau

Memperkokoh keberadaan UIN Suska Riau yang tidak hanya sebagai lembaga yang mampu mengintegrasikan islam kedalam ilmu tapi juga mampu memberikan kontribusi nyata kepada masyarakat, melalui peranan segenap civitasnya dalam penyebaran ilmu Islam yang bermanfaat, terutama dalam hal peningkatan perekonomian.

\section{KAJIAN TEORITIK}

\section{Kemiskinan}

Menurut Levitan (1980; dalam Suyanto, 2013), kemiskinan adalah kekurangan barang-barang dan pelayanan-pelayanan yang dibutuhkan untuk mencapai kehidupan yang layak. Sementara itu Schiler dalam Suyanto (2013) kemiskinan adalah ketidak sanggupan untuk mendapatkan barangbarang dan pelayanan-pelayanan yang memadai untuk memenuhi kebutuhan sosial yang terbatas. Berdasarkan definisi diatas, kemiskinan adalah ketidak mampuan untuk mendapatkan barang dan pelayanan yang memadai guna memenuhi kebutuhan sosial dan kehidupan yang layak.

\section{Indikator Kemiskinan}

Menurut Sudarmi (2008), indikator kemiskinan adalah a) Ketidakmampuan memenuhi kebutuhan konsumsi dasar (sandang, pangan dan papan); b) Tidak adanya akses terhadap kebutuhan hidup dasar lainnya (kesehatan, pendidikan, sanitasi, air bersih dan transportasi); c) Tidak adanya jaminan masa depan (karena tiadanya investasi untuk pendidikan dan keluarga); d) Kerentanan terhadap 
goncangan yang bersifat individual maupun masal; e) Rendahnya kualitas sumber daya manusia dan terbatasnya sumber daya alam; f) Kurangnya apresiasi dalam kegiatan sosial masyarakat; g) Tidak adanya akses dalam lapangan kerja dan mata pencaharian yang berkesinambungan; h) Ketidakmampuan untuk berusaha karena cacat fisik maupun mental; i) Ketidakmampuan dan ketidaktergantungan sosial (anak-anak terlantar, wanita korban kekerasan rumah tangga, janda miskin, kelompok marginal dan terpencil).

\section{Pengentasan Kemiskinan}

Adapun Upaya dalam pengentasan kemiskinan adalah sbb:

a. Meningkatkan sumber daya ekonomi yang dimiliki penduduk miskin.

Caraya adalah dengan memberikan bekal keterampilan untuk mengolah barang-barang bekas disektiarnya, misalnya kaleng bekas, besi bekas, plastik bekas, membimbing penduduk untuk jeli memerhatikan dan memanfaatkan peluang usaha disekitarnya. Contohnya penduduk yang tinggal didaerah rawa dimanfaatkan eceng gondok untuk bahan kerajinan, penduduk didaerah gunung memanfaatkan bunga pinus sebagai kerajinan, dan lain-lain.

b. Memberikan program penyuluhan dan pembekalan keterampilan Pemerintah hendaknya intensif terjun ke masyarakat untuk memberikan pengajaran dan pelatihan keterampilan bagi penduduk miskin agar dapat menghasilkan sesuatu guna menunjang pendapatannya.

c. Menyediakan pasar-pasar bagi penjualan produksi penduduk

Pasar merupakan fasilitas penting dalam menunjang pendapatan penduduk. Selain sebagai tempat memasarkan hasil produksi masyarakat, keberadaan pasar juga bisa memotivasi masyarakat untuk lebih produktif lagi. karena masyarakat tidak perlu khawatir lagi akan mengalami kesulitan memasarkan hasil produksinya.

\section{Pelatihan}

Menurut Noe dkk (2003), pelatihan merupakan suatu usaha yang terencana untuk memfasilitasi pembelajaran tentang pekerjaan yang berkaitan dengan pengetahuan, keahlian dan perilaku oleh para pegawai. 
Sementara itu menurut Gomes (2003), pelatihan adalah setiap usaha untuk memperbaiki performansi pekerja pada suatu pekerjaan tertentu yang sedang menjadi tanggung jawabnya, atau satu pekerjaan yang ada kaitannya dengan pekerjaannya. Dari defenisi diatas, pelatihan bisa dimaknai sebagai usaha terencana untuk memfasilitasi pembelajaran tentang pekerjaan atau memperbaiki kinerja seseorang secara pengetahuan, keahlian atau perilaku.

\section{Ekonomi Kreatif}

Ekonomi kreatif atau yang sering disebut juga dengan industri kreatif adalah kumpulan aktivitas ekonomi yang terkait dengan penciptaan atau penggunaan pengetahuan dan informasi. Menurut Howkins, Ekonomi Kreatif terdiri dari periklanan, arsitektur, seni, kerajinan. desain, fashion, film, musik, seni pertunjukkan, penerbitan, Penelitian dan Pengembangan (R\&D), perangkat lunak, mainan dan permainan, televisi dan radio, dan permainan video). Industri kreatif dipandang semakin penting dalam mendukung kesejahteraan dalam perekonomian. Berbagai pihak kemudian berpendapat bahwa kreativitas manusia adalah sumber daya ekonomi utama dan bahwa industri abad kedua puluh satu akan tergantung pada produksi pengetahuan melalui kreativitas dan inovasi.

Kementerian Perdagangan Indonesia menyatakan bahwa Industri kreatif adalah industri yang berasal dari pemanfaatan kreativitas, keterampilan serta bakat individu untuk menciptakan kesejahteraan serta lapangan pekerjaan dengan menghasilkan dan mengeksploitasi daya kreasi dan daya cipta individu tersebut. Adapun subsektor yang merupakan industri berbasis kreativitas di Indonesia berdasarkan pemetaan industri kreatif yang telah dilakukan oleh Departemen Perdagangan Republik Indonesia adalah:
a. Periklanan
b. Arsitektur
c. Pasar Barang Seni
d. Kerajinan
e. Desain
f. Fesyen
g. Video
h. Permainan Interaktif
i. Musik
j. Seni Pertunjukan 
k. Penerbitan dan Percetakan

1. Layanan Komputer dan Piranti Lunak

m. Televisi dan Radio

n. Riset dan Pengembangan

o. Kuliner

\section{Pelatihan Ekonomi Kreatif}

Berdasarkan uraian tentang pelatihan dan ekonomi kreatif diatas, dapatlah didefenisikan bahwa pelatihan ekonomi kreatif merupakan usaha terencana untuk memfasilitasi seseorang secara pengetahuan, keahlian dan perilaku dengan aktivitas ekonomi yang terkait dengan penciptaan dan informasi.

\section{Pengabdian Yang Relevan}

Pemberdayaan Usaha Ekonomi Produktif Bagi Masyarakat Miskin Di Kota Yogyakarta oleh Penny Rahmawaty, M.Si, dkk (Universitas Negeri Yogyakarta, 2012). Penny dkk (2012) melakukan pemberdayaan usaha ekonomi produktif bagi masyarakat miskin di Kota Yogyakarta dengan sasaran strategis adalah masyarakat yang tergolong kedalam Keluarga Menuju Sejahtera (KMS) yang berada di Kecamatan Kraton yang tersebar dalam tiga kelurahan. Jumlah peserta pelatihan sebanyak 20 orang yang terdiri atas pria dan wanita. Kegiatan pengabdian mereka didukung oleh Kecamatan Kraton Kota Yogyakarta dan Dinas Sosial Kota Yogyakarta. Penny dkk mengidentifikasi masalah yang dihadapi oleh masyarakat kota Yogyakarta adalah sbb: 1) Jumlah masyarakat miskin Kota Yogyakarta cenderung meningkat; 2) Peluang usaha yang ada relatif masih terbatas; 3) Belum optimalnya usaha ekomomi produktif; dan 4) Keterbatasan akses pasar bagi kelompok usaha. Dari masalah yang teridentifikasi diatas, maka masalah yang hendak mereka selesaikan dalam pengabdian pada masyarakat adalah bagaimana memberdayakan masyarakat miskin di Kota Yogyakarta melalui usaha ekonomi produktif. Adapun tujuan yang ingin mereka peroleh dari kegiatan pengabdian ini adalah: 1) Menumbuhkan semangat berwirausaha bagi masyarakat miskin melalui pembentukan kelompok usaha bersama; dan 2) Memberdayakan potensi masyarakat miskin dalam meningkatkan pendapatan keluarga melalui peningkatan usaha ekonomi produktif. 
Selanjutnya, manfaat kegiatan yang dicapai adalah: 1) Memberi alternatif usaha pada masyarakat, sehingga dapat meningkatkan kesejahteraan keluarga; dan 2) Membekali masyarakat untuk memiliki jiwa kewirausahaan dalam mengembangkan usaha ekonomi produktif. Untuk mencapai tujuan dan manfaat yang diinginkan diatas, mereka melakukan berbagai pemecahan masalah sebagai berikut: 1) Memberi pemahaman mengenai kewirausahaan sebagai modal awal dalam mengembangkan usaha dimana bentuk kegiatannya adalah pelatihan motivasi berusaha dan kewirausahaan; dan 2) Mengembangkan usaha ekonomi produktif dalam bentuk Kelompok Usaha Bersama yang didasarkan pada potensi kelompok. Oleh karena itu, materi pelatihan yang mereka berikan ditekankan pada: 1) Kewirausahaan; 2) Menemukan Peluang Usaha; 3) Manajemen usaha; 4) Peningkatan keterampilan, berupa pelatihan pembuatan produk yang disesuaikan dengan potensi warga masyarakat seperti kuliner, dan kerajinan.
Pelatihan yang akan kami lakukan dalam pengabdian masyarakat di kecamatan Tanah Putih nanti, memiliki kesamaan dengan pengabdian yang Penny dkk lakukan dalam hal tujuan yang ingin dicapai yaitu untuk mengentaskan kemiskinan dengan membangkitkan kemampuan masyarakat dalam berwirausaha. Namun, bila Penny dkk memberikan pelatihannya kepada masyarakat miskin sebagai sasaran, maka kami memilih pengurus dan anggota Karang Taruna agar bisa menjadi agent of change terhadap kehidupan perekonomian masyarakat yang tersebar luas di wilayah kecamatanyang notabene tidak bisa kami jangkau dalam waktu yang singkat.Disamping itu, dalam pengabdian kami, pelatihan yang akan kami berikan adalah pelatihan ekonomi kreatif yang mengubah barang bekas menjadi barang yang punya nilai jual secara ekonomi, sementara Penny dkk lebih menekankan pelatihan mereka kepada produk potensial yang sudah ada di masyarakat seperti kuliner dan kerajinan.

Pelatihan Kewirausahaan Bagi Guru dan Siswa Pengurus Osis SMAN 14 
Surabaya oleh Dra. ec. Liliana Inggrit W., MM dkk (Universitas Surabaya, 2012)

Dra. Ec. Liliana Inggrit W., MM dkk (2012) dari Jurusan Manajemen Fakultas Bisnis dan Ekonomika Universitas Surabaya juga melakukan pengabdian kepada masyarakat di SMAN 14 Surabaya dengan jumlah sasaran guru sebanyak 12 orang dan siswa pengurus Osis SMAN 14 Surabaya sebanyak 25 orang. Sasaran kegiatan masyarakat yang mereka lakukan mencakup tiga hal, yaitu: 1) Terciptanya kesadaran tentang kewirausahaan sebagai salah satu alternatif untuk meningkatkan pendapatan; 2) Meningkatkan pemahaman tentang kewirausahaan; dan 3) Meningkatkan budaya peduli masyarakat berbasis manajemen dan kewirausahaan di kalangan sivitas akademika Jurusan Manajemen FEB Universitas Surabaya. Oleh sebab itu, ruang lingkup pelatihan mencakup aspek pemasaran, aspek sumberdaya manusia, aspek produksi/operasi dan aspek keuangan yang disampaikan dalam bentuk presentasi oleh Tim Pengabdi. Setelah materi dipresentasikan, kegiatan dilanjutkan dengan klinik dimana peserta kegiatan diberikan materi berupa kasus yang didiskusikan dalam kelompok, dan dipecahkan sesuai dengan pertanyaan yang terdapat dalam kasus. Pertanyaan yang terdapat dalam kasus mencakup materi yang telah dipresentasikan sebelumnya. Untuk menjawab pertanyaan tersebut, kelompok peserta dapat melakukan konsultasi kepada tim konsultan yang telah ditetapkan. Hasil dari pembahasan kasus ini dipresentasikan di kelas untuk mendapat masukan dari tim yang lain. Keluaran dari kegiatan pengabdian kepada masyarakat tentang kewirausahaan ini adalah terbentuknya pemahaman yang baik tentang kewirausahaan, yang ditinjau dari aspek manajemen pemasaran, manajemen sumberdaya manusia, manajemen jejaring bisnis, dan manajemen keuangan.

Pelatihan yang diberikan oleh Liliana Inggrit dkk dalam pengabdian masyarakat mereka adalah pelatihan kewirausahaan, sama seperti pelatihan yang akan kami berikan kepada Karang 
Taruna Kecamatan Tanah Putih Kabupaten Rokan Hilir. Namun demikian, walaupun pelatihan kewirausahaan ini memiliki kesamaan lain yaitu sama-sama untuk membentuk pemahaman akan kewirausahaan, pelatihan yang akan kami berikan lebih luas dalam tujuan yang akan dicapai yaitu tidak hanya sekedar pemahaman akan kewirausahaan tapi juga melatih para peserta untuk langsung menghasilkan produk dari barang bekas menjadi barang yang punya nilai jual secara ekonomi.

Pelatihan Kewirausahaan Guna Pengembangan Ekonomi Kreatif Di Desa Triharjo Pandak Bantul Oleh: Abdullah Taman, Msi., Ak, dkk (Universitas Negeri Yogyakarta, 2014)

Abdullah Taman dkk (2014) dalam pengabdiannya kepada 25 orang anggota Karang Taruna Desa Triharjo Pandak Bantul Yogyakarta, memberikan pelatihan kewirausahaan untuk pengembangan ekonomi kreatif. Identifikasi masalah yang mereka dapatkan adalah sbb: 1) Bagaimana cara meningkatkan pengetahuan dan pemahaman pemuda di Desa Triharjo tentang persaingan ekonomi global?; 2) Bagaimana menyadarkan pemuda akan peran penting pemuda Desa Triharjo bagi perekonomian bangsa di masa depan? 3) Bagaimana meningkatkan jiwa kewirausahaan pemuda Desa Triharjo? 4) Bagaimana membuat rencana usaha kreatif bagi pemuda di Desa Triharjo? Dari identifikasi masalah tersebut, tujuan pelatihan dibuat untuk: 1) Menimbulkan kesadaran peserta akan ekonomi global dan peran pemuda dalam ekonomi Indonesia di masa depan dapat meningkat; 2) Meningkatkan Jiwa kewirausahaan peserta, 3) Peserta mampu memilih usaha kreatif; dan 4) Peserta mampu menyusun rencana usaha kreatif. Adapun manfaat dari pelatihan dalam pengabdian ini adalah untuk memberi bekal kepada para pemuda di Desa Triharjo sebagai generasi penggerak perekonomian Indonesia di masa depan dengan membentuk ekonomi kreatif, yaitu berbagai industri kreatif dengan memanfaatkan potensi sumber daya alam. Disamping itu, secara khusus, pelatihan kewirausahaan diberikan 
untuk meningkatkan motivasi dan jiwa kewirausahaan bagi para pemuda serta penyajian berbagai jenis industri kreatif yang dilanjutkan dengan pembuatan rencana usaha, yang diharapkan akan memberikan pengetahuan, pemahaman, serta keterampilan bagi pemuda untuk merencanakan usaha kreatif, sehingga dapat meningkatkan ekonomi di Desa Triharjo. Oleh karena itu, Abdullah Taman dkk melakukan langkah operasional mereka dengan cara sebagai berikut: 1) Memberikan pengetahuan peserta mengenai ekonomi global dan peran pemuda dalam ekonomi Indonesia di masa depan; 2) Memotivasi peserta pentingnya meningkatkan jiwa wirausaha; 3) Menyelenggarakan pelatihan kewirausahaan yang meliputi pengertian wirausaha, arti penting wirausaha, peluang usaha, sampai dengan contoh usaha kreatif dengan memanfaatkan potensi lokal berupa sumber daya alam; dan 4) Membimbing Pembuatan rencana usaha kreatif pada masingmasing dengan didampingi oleh TIM Pengabdian Pada Masyarakat. Adapun metode yang digunakan dalam melakukan langkah operasional tersebut adalah dengan metode ceramah, tutorial dan diskusi.

Pengabdian masyarakat yang akan kami lakukan nanti juga menempatkan anggota karang taruna sebagai sasaran sebanyak 25 orang dan membimbing untuk membuat usaha kreatif akan tetapi yang membedakan dari yang dilakukan oleh Abdullah Taman dkk adalah bahwa usaha kreatif yang kami berikan kepada pengurus dan anggota Karang Taruna Kecamatan Tanah Putih merupakan bentuk kreatifitas mengubah barang bekas menjadi barang yang punya nilai jual secara ekonomi. Disamping itu pelatihan yang kami berikan cenderung dengan menggunakan pendekatan kedewasaan, learning by doing dan learning by experience (Basleman, 2003) sehingga pendekatan yang dipakai adalah pendekatan kedewasaan yang mengubah pola pikir, tingkah laku dan sikap mental para peserta secara praktis, sehingga jauh dari kesan ceramah dan tutorial.

\section{MATERI DAN METODE}

\section{Kerangka Pemecahan Masalah}


Ada banyak cara yang dapat dilakukan untuk mengatasi masalah kemiskinan di masyarakat Kecamatan Tanah Putih Kabupaten Rokan Hilir Provinsi Riau, salahsatunya adalah dengan memberikan program penyuluhan dan pembekalan keterampilan. Oleh sebab itu, Pengabdi berpendapat salah satu pelatihan yang tepat diberikan untuk pengentasan kemiskinan adalah Pelatihan Ekonomi Kreatif Bagi Pemuda Karang Taruna. Secara sederhana, kerangka pemecahan masalah dapat dibuat sebagai berikut:

\begin{tabular}{|l|}
\hline \multicolumn{1}{|c|}{ Permasalahan: } \\
1. \\
Masyarakat \\
Miskin \\
2. \\
Pemuda Karang \\
Taruna belum \\
berfungsi untuk \\
menyukseskan \\
pembangunan \\
pemerintah \\
seperti yang \\
tertuang dalam
\end{tabular}

\section{Realisasi Penyelesaian Masalah}

Berdasarkan rangkaian kegiatan dan materi yang diberikan dalam

\section{Solusi:}

Pemuda Karang

Taruna diberi

Pelatihan Ekonomi

Kreatif oleh

Pengabdi dari

LPPM UIN Suska

Riau

\section{Hasil:}

1. Tumbuhnya kesadaran pemuda untuk mengentaskan kemiskinan

2. Bertambahnya pengetahuan, dan keterampilan pemuda tentang ekonomi kreatif

3. Pemuda dapat membuat usaha ekonomi kreatif

Tabel 1. Realisasi Penyelesaian Masalah

\begin{tabular}{|l|l|l|}
\hline \multicolumn{1}{|c|}{ TUJUAN } & $\begin{array}{r}\text { INDIKATOR } \\
\text { KETERCAPAIAN }\end{array}$ & \multicolumn{1}{c|}{ TOLAK UKUR } \\
\hline $\begin{array}{l}\text { Peserta } \\
\text { termotivasi } \\
\text { untuk }\end{array}$ & $\begin{array}{l}\text { Peserta memiliki berbagai } \\
\text { keinginan yang baik untuk } \\
\text { mengentaskan } \\
\text { peningkatan taraf hidup }\end{array}$ & $\begin{array}{l}\text { Peserta dapat } \\
\text { menyebutkan contoh } \\
\text { keinginan -keinginan } \\
\text { dirinya di masa yang akan }\end{array}$ \\
\hline $\begin{array}{l}\text { Peserta } \\
\text { mengetahui dan } \\
\text { memahami } \\
\text { peluang usaha }\end{array}$ & $\begin{array}{l}\text { mampu menyusun rencana } \\
\text { usaha dengan }\end{array}$ & $\begin{array}{l}\text { Peserta menyelesaikan } \\
\text { remana usaha kreatif. }\end{array}$ \\
\hline
\end{tabular}




\begin{tabular}{|l|l|l|}
\hline ekonomi kreatif. & bekas. & \\
\hline Peserta dapat & Peserta mampu & Peserta dapat mendirikan \\
membuat & mendirikan usaha kreatif & usaha baru secara individu \\
produk ekonomi & yang baru dengan & atau kelompok. \\
kreatif dari & memanfaatkan barang & \\
barang bekas & bekas. & \\
\hline
\end{tabular}

Disamping hal diatas, untuk menilai keberhasilan program pengabdian ini, hal yang juga diamati dan diukur adalah bahwa:

a. $90 \%$ - $100 \%$ peserta yang diundang hadir dalam pelatihan.

b. Terlaksananya seluruh kegiatan pelatihan kewirausahaan

c. $80 \%$ - $100 \%$ peserta mampu mengembangkan usaha ekonomi kratif

d. Pernyataan kepuasan dari peserta pelatihan dan pemerintah setempat.

\section{Kelompok Sasaran}

Kelompok atau khalayak sasaran dalam pengabdian ini adalah masyarakat Kecamatan Tanah Putih Kabupaten Rokan Hilir Provinsi Riau yang karena keterbatasan waktu, tenaga dan biaya diwakili oleh Pemuda pengurus dan anggota Karang Taruna.

\section{Metode Pelaksanaan}

Pelatihan Ekonomi Kreatif
Untuk Pengentasan Kemiskinan Bagi Pemuda Karang Taruna Kecamatan Tanah Putih Provinsi Riau dilakukan dengan metode sebagai berikut:

a. Presentasi. Untuk meningkatkan pengetahuan, pemahaman dan keterampilan peserta pelatihan, pengabdi memberikan presentasi untuk setiap materi pelatihan. Adapun materi pelatihan yang diberikan adalah:

1. Kemiskinan, Penyebab dan Penanggulangannya

2. Ekonomi Kreatif dan Peluang Usaha Untuk Mengentaskan Kemiskinan di Kecamatan Tanah Putih Kabupaten Rokan Hilir Provinsi Riau

3. Produk-Produk Ekonomi Kreatif dari Barang Bekas seperti: dompet, kotak tisu, kotak pensil, kotak beras, tempat telor dan tas Yang bahan-bahannya didapat 
dari lingkungan kecamatan tanah putih kabupaten rokan hilir provinsi riau

b. Permainan. Untuk menguatkan daya serap peserta terhadap materi pelatihan, pengabdi disela-sela presentasi memberikan permainanpermainan atraktif dan kreatif yang berhubungan dengan materi pelatihan tersebut.

c.Studi Kasus

Disamping permainan, pengabdi juga memberikan contoh-contoh kasus kemiskinan di beberapa daerah yang bisa terperbaiki setelah mendapatkan pelatihan ekonomi kreatif seperti yang peserta terima.

\section{d. Brain Storming}

Untuk mendapatkan hasil pelatihan yang maksimal, setelah presentasi, pengabdi melakukan brain storming dengan peserta pelatihan tentang apa yang sudah dipresentasikan agar terjadi perubahan pola pikir, tingkah laku dan sikap mental terhadap peserta tersebut.

e. Tanya Jawab

Setelah semua langkah diatas dilakukan, terakhir pengabdi membuka sesi Tanya jawab dengan peserta pelatihan untuk mendapatkan sebuah kesimpulan bahwa semua materi yang diberikan telah diterima, dipahami dan dikuasai dengan baik oleh peserta (terjadi perubahan secara afektif, kognitif dan psikomotorik pada peserta).

f. Pendekatan Kedewasaan

Semua langkah-langkah diatas dilakukan dengan pendekatan kedewasaan, yaitu pengabdi menempatkan diri sebagai teman dan mitra dari peserta pelatihan agar tidak ada jarak yang menjadi penghalang dalam penyampaian materi. Untuk pendekatan kedewasaan ini, pengabdi mengedepankan learning by doing (mengajak peserta belajar sambil melakukan) dan learning by experience (mengajak peserta belajar dari kesalahan-kesalahan yang mereka lakukan selama pelatihan).

\section{HASIL DAN PEMBAHASAN}

Pelatihan Ekonomi Kreatif Untuk Pengentasan Kemiskinan Bagi Pemuda Karang Taruna Kecamatan Tanah Putih Provinsi Riau telah terlaksana sesuai dengan tujuan. Secara 
teknis pelaksanaan, setelah acara dibuka oleh Camat Kecamatan Tanah Putih Kabupaten Rokan Hilir Provinsi Riau, pelatihan dimulai dengan presentasi pembuka wawasan, pengetahuan, pemahaman serta untuk membangkitkan semangat dan motivasi peserta. Adapun materi yang dipresentasikan adalah:

a. Kemiskinan, Penyebab dan Penaggulangannya Oleh Dra. Meimunah S Moenada, M. Ag

b. Ekonomi Kreatif dan Peluang Usaha Untuk Mengentaskan Kemiskinan di Kecamatan Tanah Putih Kabupaten Rokan Hilir Provinsi Riau Oleh Hendra Riofita, MM

Setelah materi diatas dipresentasikan, pengabdi kemudian memberikan pelatihan tentang cara-cara membuat produk-produk ekonomi kreatif yang bahan-bahannya mudah didapat di lingkungan Kecamatan Tanah Putih Kabupaten Rokan Hilir Provinsi Riau, seperti: produk dompet dan tempat tisu dari bekas bungkus sasetan, tempat pensil dan lampu tidur dari botol minuman bekas, tempat beras dan tas dari plastik deterjen bekas serta tempat telor dari gelas minuman. Pelatihan Ekonomi Kreatif Untuk Pengentasan Kemiskinan Bagi Pemuda Karang Taruna Kecamatan Tanah Putih Kabupaten Rokan Hilir Provinsi Riau dihadiri oleh $100 \%$ peserta atau sejumlah 30 orang. Adapun hasil yang didapat adalah:

Tabel 2. Hasil Pelatihan

\begin{tabular}{|c|c|c|c|}
\hline MATERI & TUJUAN & $\begin{array}{c}\text { INDIKATOR } \\
\text { KETERCAPAIAN }\end{array}$ & HASIL \\
\hline \begin{tabular}{l}
\multicolumn{2}{l}{ Kemiskinan, } \\
Penyebab dan \\
Penanggulangan \\
nya $\quad$ Oleh \\
Dra. Meimunah \\
S Moenada, \\
M.Ag
\end{tabular} & $\begin{array}{l}\text { Peserta } \\
\text { termotivasi } \\
\text { untuk } \\
\text { mengentaskan } \\
\text { kemiskinan }\end{array}$ & $\begin{array}{l}\text { Peserta memiliki } \\
\text { berbagai keinginan } \\
\text { yang baik untuk } \\
\text { peningkatan taraf } \\
\text { hidup }\end{array}$ & $\begin{array}{l}\text { Peserta antusias } \\
\text { ingin membuka } \\
\text { usaha }\end{array}$ \\
\hline Ekonomi Kreatif & Peserta & Peserta mampu & Peserta membuat \\
\hline
\end{tabular}




\begin{tabular}{|c|c|c|c|}
\hline $\begin{array}{l}\text { dan Peluang } \\
\text { Usaha Untuk } \\
\text { Mengentaskan } \\
\text { Kemiskinan di } \\
\text { Kecamatan } \\
\text { Tanah Putih } \\
\text { Kabupaten } \\
\text { Rokan Hilir } \\
\text { Provinsi Riau } \\
\text { Oleh Hendra } \\
\text { Riofita, MM }\end{array}$ & $\begin{array}{l}\text { mengetahui dan } \\
\text { memahami } \\
\text { peluang usaha } \\
\text { ekonomi kreatif. }\end{array}$ & $\begin{array}{l}\text { menyusun rencana } \\
\text { usaha dengan } \\
\text { memanfaat kan } \\
\text { barang bekas. }\end{array}$ & $\begin{array}{l}\text { rencana usaha } \\
\text { kreatif untuk } \\
\text { didirikan secara } \\
\text { individu atau } \\
\text { bersama-sama. }\end{array}$ \\
\hline $\begin{array}{l}\text { Mengubah } \\
\text { barang bekas } \\
\text { menjadi barang } \\
\text { bernilai ekonomi } \\
\text { Oleh team } \\
\text { Pengabdi }\end{array}$ & $\begin{array}{l}\text { Peserta membuat } \\
\text { produk ekonomi } \\
\text { kreatif dari } \\
\text { barang bekas }\end{array}$ & $\begin{array}{l}\text { Peserta mampu } \\
\text { memanfaatkan } \\
\text { barang bekas untuk } \\
\text { dirubah menjadi } \\
\text { barang bernilai } \\
\text { ekonomi. }\end{array}$ & $\begin{array}{l}\text { Peserta dapat } \\
\text { membuat produk } \\
\text { ekonomi kreatif } \\
\text { dari barang bekas } \\
\text { seperti: dompet, } \\
\text { tempat tisu, } \\
\text { tempat pensi, } \\
\text { lampu tidur, tas, } \\
\text { tempat beras dan } \\
\text { tempat telor }\end{array}$ \\
\hline
\end{tabular}

KESIMPULAN DAN SARAN

Kesimpulan

Pelatihan Ekonomi Kreatif

Untuk Mengentaskan Kemiskinan Bagi

Pemuda Karang Taruna Kecamatan

Tanah Putih Kabupaten Rokan Hilir

Provinsi Riau telah berhasil dilaksanakan sesuai dengan tujuan yaitu:

a. Menjadikan pemuda Karang Taruna Kecamatan Tanah Putih Kabupaten Rokan Hilir sebagai ujung tombak pengentas kemiskinan melalui kemampuan meningkatkan usaha ekonomi kreatif bagi dirinya, 
organisasinya dan masyarakat disekitarnya.

b. Melatih pemuda Karang Taruna Kecamatan Tanah Putih Kabupaten Rokan Hilir untuk dapat melakukan usaha ekonomi kreatif dengan mengubah barang bekas menjadi barang yang punya nilai jual

c. Membantu pemuda Karang Taruna Kecamatan Tanah Putih Kabupaten Rokan Hilir untuk dapat membuat usaha ekonomi kreatif.

\section{Saran}

Adapun saran yang pengabdi sampaikan adalah:

a. Bagi Pemerintah:

1. Agar pemerintah baik ditingkat Kecamatan, Kabupaten maupun Provinsi memilik agenda dan atau program kerja pembinaan bagi anggota Karang Taruna di Kecamatan Tanah Putih Kabupaten Rokan Hilir Provinsi Riau untuk membuka lapangan kerja khususnya di bidang ekonomi kreatif.

2. Agar pemerintah baik di tingkat Kecamatan, Kabupaten maupun Provinsi membantu permodalan bagi anggota Karang Taruna di
Kecamatan Tanah Putih

Kabupaten Rokan Hilir Provinsi Riau.

b. Bagi Pemuda Karang Taruna Kecamatan Tanah Putih Kabupaten Rokan Hilir Provinsi Riau:

1. Agar menjadi pelopor bagi masyarakat Kecamatan Tanah Putih Kabupaten Rokan Hilir Provinsi Riau.

2. Agar selalu menumbuhkan, menjaga dan mengembangkan jiwa kewirausahaan khususnya dibidang ekonomi kreatif supaya peningkatan taraf hidup dan pengentasan kemiskinan di Kecamatan Tanah Putih Kabupaten Rokan Hilir Provinsi Riau dapat terwujud.

\section{DAFTAR PUSTAKA}

Allan, Tan, M.G., dan Soemardjan, S, Kemiskinan Struktural, Suatu Bunga Rampai. Jakarta: YIIS, 1980

Basleman, Anisah, dkk, Teori Belajar Orang Dewasa, Bandung: Penerbit Rosda, 2003.

Esmara, H. Perencanaan dan Pembangunan di Indonesia, Jakarta: Gramedia, 1986

Gomes, Faustino Cardoso, Manajemen Sumber Daya Manusia, Yogyakarta: Penerbit Andi, 2003 
Howkins, $\mathrm{n}$ John, The Creative Economy: How People Make Money, Penguin UK; 2 edition, 2013

Kempton, J., 1995. Human Resource Management and Development. London: MacMillan Press Ltd

Moeljanto, T., Pembangunan, Dilema dan Tantangan. Yogyakarta: Pustaka Pelajar, 1996

Noe, Raymond A, et al., HRM: Gaining a Competitive Advantage, $4^{\text {th }}$ edition, New York: McGrawHill/Irwin. 2003

Sudarmi, Sri, Galeri Pengetahuan Sosial Terpadu Kelas 8, Jakarta: Pusat Perbukuan Departemen Pendidikan Nasional. 2008

Suyanto, Bagong, Anatomi Kemiskinan dan Strategi Penanganannya. Malang: In-Trans Publishing. 2013

Todaro, P., Pembangunan Ekonomi di Dunia Ketiga, Jilid I. Jakarta: Ghalia Indonesia, 1983 